\title{
Effects of stand age on litter quality, decomposition rate and nutrient release of Kazdagi fir (Abies nordmanniana subsp. equi-trojani)
}

\author{
Gamze Savaci ${ }^{(1)}$, \\ Temel Sariyildiz ${ }^{(2)}$
}

\begin{abstract}
The influence of stand age on litter quality, decomposition rate and nutrient release was examined in pure stands of Kazdagi fir (Abies nordmanniana subsp. equi-trojani [Steven] Spach) differing in age $\left(\mathrm{Fir}_{38}, \mathrm{Fir}_{60}, \mathrm{Fir}_{90}\right.$ and $\mathrm{Fir}_{100}$ years). The needle litters were collected and analysed for initial total carbon, cellulose, hemicellulose, lignin and nutrient concentrations $(\mathrm{N}, \mathrm{P}, \mathrm{K}, \mathrm{Ca}, \mathrm{S}, \mathrm{Mg}$, $\mathrm{Mn}$ and $\mathrm{Fe}$ ). Initial litter quality parameters varied significantly among the four stand age classes. The $\mathrm{Fir}_{60}$ and $\mathrm{Fir}_{100}$ stands had higher total $\mathrm{C}$ than the $\mathrm{Fir}_{38}$ and $\mathrm{Fir}_{90}$ stands, while the $\mathrm{Fir}_{38}$ and $\mathrm{Fir}_{100}$ stands had higher $\mathrm{N}$ than the $\mathrm{Fir}_{60}$ and $\mathrm{Fir}_{90}$ stands. Mean cellulose and hemicellulose concentrations were highest in the $\mathrm{Fir}_{90}$ stand, while mean lignin concentration was highest in the $\mathrm{Fir}_{38}$ stand. Fir $_{90}$ stand showed the highest ratios of $\mathrm{C} / \mathrm{N}$ and Lignin/N. In general, the older fir stands showed higher $\mathrm{Ca}, \mathrm{Mg}$ and $\mathrm{K}$ concentrations and lower $\mathrm{P}$ and $\mathrm{S}$ concentrations than the younger stands. The litter, however, showed higher a Mn concentration under the $\mathrm{Fir}_{60}$. Mean Fe concentration was highest under the $\mathrm{Fir}_{38}$ stand and lowest under the $\mathrm{Fir}_{60}$ stand. Litter decomposition was studied in the field using the litterbag technique. The litterbags were placed on the soil under each stand age class and sampled every 6 months for 2 years. The interaction of stand age and time on the mass loss was significant $(p<0.01)$. The repeated measures ANOVA showed that the main effect of time on the mass loss was also significant $(p<0.001)$. Needle litters under Fir $_{100}$ and $\mathrm{Fir}_{60}$ stands decomposed faster than the needle litters under $\mathrm{Fir}_{90}$ and $\mathrm{Fir}_{38}$ stands. The calculated times required for $50 \%$ mass loss were higher under $\operatorname{Fir}_{38}(1.35 \mathrm{y})$ and $\mathrm{Fir}_{90}(1.27 \mathrm{y})$ stands than under $\mathrm{Fir}_{100}(1.05 \mathrm{y})$ and $\mathrm{Fir}_{60}(1.06$ y) stands. The litters in $\mathrm{Fir}_{38}$ and $\mathrm{Fir}_{90}$ stands need approximately 4 years for 95\% mass loss compared to the litters in $\mathrm{Fir}_{60}$ and $\mathrm{Fir}_{100}$ stands, which need 3 years. In general, $\mathrm{Ca}, \mathrm{Mg}$ and $\mathrm{S}$ concentrations increased over time, whereas $\mathrm{K}$ and $\mathrm{Mn}$ decreased. These results illustrate that stand age is a key factor to be considered when studying litter decomposition dynamics.
\end{abstract}

Keywords: Litter Quality, Stand Age, Litter Decomposition, Nutrient Release, Fir

\section{Introduction}

Plant litter decomposition has long been recognized as an essential process for nutrient cycling and organic matter turnover within ecosystems (Heal et al. 1997, Laskowski \& Berg 2006). Decomposition rate is mainly affected by climate (temperature and precipitation) and by litter quality (carbon/nitrogen $[\mathrm{C} / \mathrm{N}]$ ratio, lignin, $\mathrm{N}$ and lignin/ $\mathrm{N}$ ratio - Heal et al. 1997, Sariyildiz

2000, Sariyildiz \& Anderson 2003a). In general, climate factors govern decay rates at broad scales, whereas litter quality plays an important role in controlling decay rates at small scales (Couteaux et al. 1995, Sariyildiz $\&$ Anderson 2003b). Most of the studies on the topic investigated the influence on decay rates of either interspecific differences in litter quality within systems or differences among systems using the same litter

(1) Kastamonu University, Faculty of Forestry, Department of Forest Engineering, 37150, Kastamonu (Turkey); (2) Bursa Technical University, Faculty of Forestry, Department of Forest Engineering, 16310, Bursa (Turkey)

@ Gamze Savaci (gsavaci@kastamonu.edu.tr)

Received: Dec 02, 2019 - Accepted: Jun 22, 2020

Citation: Savaci G, Sariyildiz T (2020). Effects of stand age on litter quality, decomposition rate and nutrient release of Kazdagi fir (Abies nordmanniana subsp. equi-trojani). iForest 13: 396-403. - doi: 10.3832/ifor3306-013 [online 2020-09-03]

Communicated by: Daniela Baldantoni
(Fogel \& Cromack 1977, Berg \& Meentemeyer 2002, Inagaki et al. 2004, Joly et al. 2017). Moreover, considerable intraspecific variation in litter quality has been reported as related to factors such as tree canopy structure (Sariyildiz \& Anderson 2003b), soil characteristics (Sanger et al. 1998, Hättenschwiler et al. 2003, Sariyildiz \& Anderson 2005), topography (Sariyildiz et al. 2005) and hydrology (Carreiro et al. 1999). The differences in litter quality within tree species may also reflect both genotypic and phenotypic variations resulting from biotic and/or abiotic interactions. However, a considerable variation in litter traits under different tree genotypes has also been observed. For example, polyphenol concentrations in leaf and fine root litter vary inherently among four distinct populations of Metrosideros polymorpha, the dominant tree species in Hawaiian montane forests (Hättenschwiler et al. 2003).

While environmental heterogeneity and genetic variability have received some attention as sources of intraspecific litter quality and decay rate variability (Albert et 


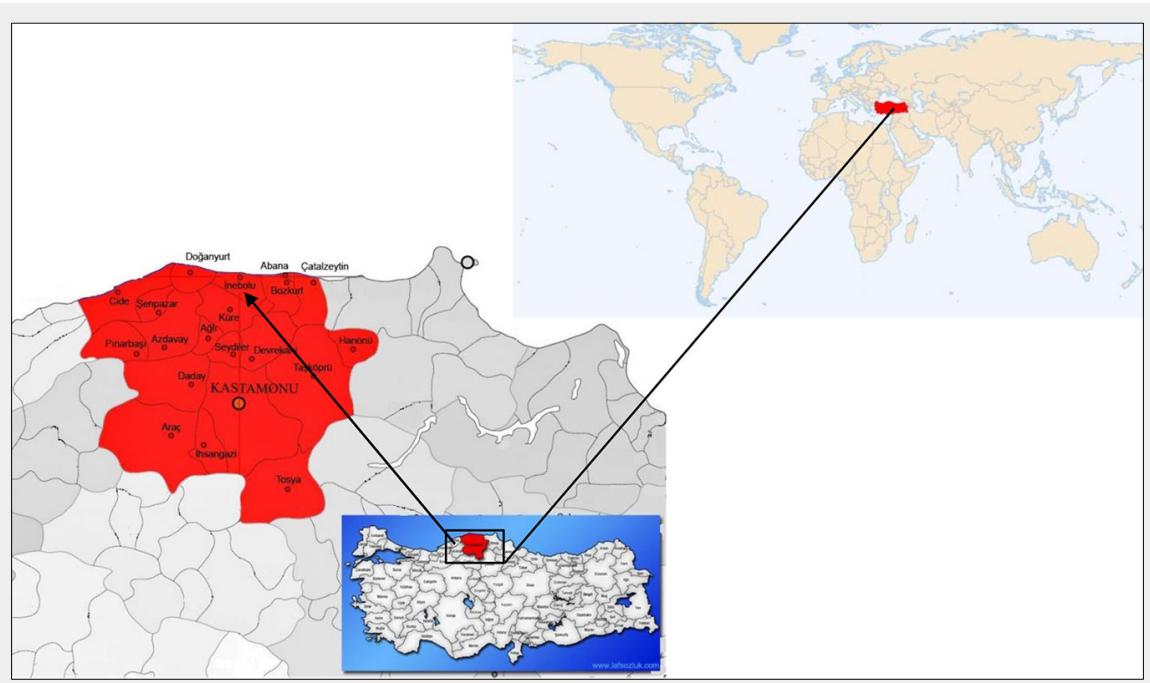

Fig. 1 - Location of the study area in northeast Turkey.

al. 2010), the role of stand age has been poorly addressed (Inagaki et al. 2004, Trap et al. 2013). Changes in photosynthesis, mineral nutrition, respiration, $C$ allocation and hydrological function during stand development were reviewed in detail by Ryan et al. (1997). Some authors proposed that the quality and quantity of soil organic matter and nutrient turnover can be influenced by forest stand age and the related changes in community structure and composition (Inagaki et al. 2004). Moreover, litter decomposition can be affected by microclimatic changes due to variations in solar radiation, wind speed or rainfall interception related to the canopy structure (Chen et al. 1999, Welke \& Hope 2005). Relative humidity, in particular, can increase in the course of secondary forest succession and promote decomposition (Lohbeck et al. 2014, Wang et al. 2014, Trogisch et al. 2016). However, there is evidence that plants can show considerable intraspecific variations in litter quality related to forest stand age (Sharma et al. 1985, Sharma \& Ambasht 1987). For example, Trap et al. (2013) showed that for pure beech (Fagus sylvatica) stands with different ages (15, 65 , 95 and 130 years), forest age is an important driver of litter quality variation. Notable results included decreasing $\mathrm{Mg}, \mathrm{N}$ and $\mathrm{K}$ concentrations during stand development and varying hemicellulose, cellulose and lignin content.

In this study, we tested the hypothesis that litter quality of Kazdagi fir (Abies nordmanniana subsp. equi-trojani [Steven] Spach) changes during its 100-year life span while controlling for climate and soil conditions. Moreover, we hypothesised that variations in litter quality parameters affect litter decomposition and nutrient release.

\section{Material and methods}

\section{Study site description and sampling}

The study was conducted in pure fir-dominated stands around the town of Inebolu, which is located in the north part of Kastamonu Province in northwest Turkey ( $41^{\circ} 51^{\prime}$ $23^{\prime \prime} \mathrm{N}, 33^{\circ} 45^{\prime} 36^{\prime \prime} \mathrm{E}$ - Fig. 1). Study site elevation is $1030 \mathrm{~m}$ a.s.l. The aspect is northeast (NE) with a mean slope of $25 \%$. The study site has a characteristic Black Sea climate with warm and rainy winters and hot but rainy summers. According to weather data for 1960-2015 (Inebolu Meteorology Station, $64 \mathrm{~m}$ a.s.l.), mean annual precipitation is $1551 \mathrm{~mm}$, ranging from $90.3 \mathrm{~mm}$ in July to $185.9 \mathrm{~mm}$ in December. The mean annual temperature is $9.3{ }^{\circ} \mathrm{C}$, reaching highs in August $\left(26.6^{\circ} \mathrm{C}\right)$ and lows in February $\left(2.7^{\circ} \mathrm{C}\right)$. The parent rock of the study site is neritic limestone and schists covered with sandy loam and clay. According to the FAO forest soil classification system, the soil of the fir stand is brown forest soil, and the humus layers were mull.

The fir is an important tree species in Turkey. Here this genus is represented by five taxa: (i) Abies nordmanniana subsp. nordmanniana Spach; (ii) Abies nordmanniana subsp. bornmuelleriana Maltfelt; (iii) Abies cilicica subsp. isaurica Coode \& Cullen; (iv) Abies cilicica subsp. cilicica Carr.; and (v) Abies nordmanniana subsp. equi-trojani Coode $\&$ Cullen. These taxa are distributed over 584,781 hectares, which accounts for $2.62 \%$ of the overall forest coverage. As an endemic taxon, Kazdagi fir (Abies nordmanniana subsp. equi-trojani) is distributed in the Central and Western Black Sea Region and South Marmara Region in Turkey (Mataraci 2012). Selective logging of the fir forests, which are natural forests in the region, is the main management type in the region.

Fir stands were classified into the following age classes according to average tree age: $38\left(\mathrm{Fir}_{38}\right), 60\left(\mathrm{Fir}_{60}\right), 90\left(\mathrm{Fir}_{90}\right)$ and 100 $\left(\mathrm{Fir}_{100}\right)$ years old. For each stand age class, three subplots $\left(20 \times 20 \mathrm{~m}=400 \mathrm{~m}^{2}\right)$ were chosen. Freshly fallen fir-needle litters were collected from a total of twelve subplots ( 3 replicates $\times 4$ age classes $=12$ subplots). Litters showed no visible signs of discolouration or fungal colonization. The needle litters were air-dried in the laboratory and then oven-dried at $40{ }^{\circ} \mathrm{C}$ for $48 \mathrm{~h}$. The oven-dried samples were then stored in plastic bags at $6^{\circ} \mathrm{C}$ until the analyses.

Stand characteristics (height, diameter and canopy closure) were measured in each subplot. Measurements of diameter at breast height (DBH) and tree height were conducted on three sample trees in each stand age class. DBH was measured using a diameter tape. Trees were cored at breast height to determine tree age using the dendrochronological approach. Tree heights were measured with a Blume-Leiss clinometer.

Soil samples were taken under the same trees from which the fir needle litter was collected. Soil samples were collected in an area of $0.5 \times 0.5 \mathrm{~m}^{2}$ at a distance of $2 \mathrm{~m}$ from the base of the trunk and at a depth of $0-20 \mathrm{~cm}$. The moist field samples were sieved $(<2 \mathrm{~mm})$ to remove stones, roots and macro-fauna and bulked to give a single representative soil sample for each age class. Stand and soil characteristics are shown in Tab. 1.

\section{Needle litter and soil analysis}

The stored needle litters were oven-dried at $85{ }^{\circ} \mathrm{C}$, ground in a laboratory mill to a mesh fraction less than $1 \mathrm{~mm}$ and analysed for organic C, total N, P, K, Ca, Mg, S, Mn, $\mathrm{Fe}, \mathrm{ADF}$ (acid detergent fibre), lignin and cellulose concentrations.

Organic $\mathrm{C}$ and $\mathrm{N}$ concentrations were measured using a CNH-S elementary analyser (EA $3000^{\circledR}$ V.3.0 single, Eurovector, Milan, Italy) according to the dry combustion method. Nutrient concentrations $(\mathrm{P}, \mathrm{K}, \mathrm{Ca}$, $\mathrm{Mg}, \mathrm{S}, \mathrm{Mn}, \mathrm{Fe}$ ) in the needle litters were analysed using an energy dispersive X-ray Fluorescence Spectrometer (EDXRF Xepos II ${ }^{\infty}$, Spectro-Analytical Instruments $\mathrm{GmbH}$, Kleve, Germany). Certified soil reference material (NIST SRM 2709) was used to assess the accuracy of the EDXRF analyses.

Acid detergent fibre (ADF), a-cellulose and lignin were determined using the ADFsulphuric lignin method by Rowland \& Roberts (1994). ADF was calculated as the mass loss after heating a $0.5 \mathrm{~g}$ tared sample for $1 \mathrm{~h}$ with acidified cetryltrimethyl ammonium bromide and filtering the suspension through a tared glass sinter, followed by drying and reweighing. Cellulose was calculated as the mass loss after acidification of the ADF with $72 \% \mathrm{H}_{2} \mathrm{SO}_{4}$, and lignin was calculated from the residual mass of filtrate after ignition at $550^{\circ} \mathrm{C}$ for $2 \mathrm{~h}$.

Soil pH $\left(\mathrm{H}_{2} \mathrm{O}\right)$ was measured in a 1:2.5 mixture of deionized water and soil using a glass calomel electrode ( $\mathrm{pH} 5$ Series meter, LaMotte, Chestertown, MSD, USA) after equilibration for $1 \mathrm{~h}$ in solution (Jackson 1962). Soil moisture content on fresh soil samples was calculated by weight loss after drying approximately $10 \mathrm{~g}$ of soil for 24 h at $105{ }^{\circ} \mathrm{C}$ (Allen 1989). Bulk density was determined by weight loss after drying the undisturbed soil cores. Soil texture (sand, 
silt and clay) was determined using the hydrometer method of Bouyoucos (1962). All analyses were performed in triplicate.

\section{Needle litter decomposition}

The litterbag method (Bocock \& Gilbert 1957) was used to measure the decomposition rates of the different needle litters in the field. Litterbags $(20 \times 20 \mathrm{~cm})$ were made of 0.1-mm nylon with a mesh size of $1.5 \mathrm{~mm}$ to allow for inclusion of mesofauna but exclusion of macrofaunal detritivores.

Each bag was filled with $5 \mathrm{~g}$ of needle litter that was air-dried at room temperature until a constant weight was reached. Subsamples of the needle litter were taken to determine the moisture content by drying at $85{ }^{\circ} \mathrm{C}$. For each age class, the litterbags were prepared and placed in the original site where the needle litter was collected.

The number of needle litterbags used in the field experiment was 80 (4 stand age classes $\times 4$ removal dates $\times 5$ replicates). The needle litterbags were numbered and fixed to the ground of the corresponding site with metal pegs. Five litterbags were harvested from each age class after 6, 12, 18 and 24 months to evaluate needle litter decay over time. Percentage loss of initial mass was calculated after drying samples at $85^{\circ} \mathrm{C}$.

The needle litter decomposition rate $(k)$ was calculated from the percentage of dry mass remaining using an exponential decay model (Olson 1963 - eqn. 1)

$$
W_{t} / W_{o}=e^{-k t}
$$

where $W_{t} / W_{0}$ is the fraction of initial mass remaining at time $t, t$ is the elapsed time (years) and $k$ is the decomposition constant $\left(y^{-1}\right)$. As suggested by Olson (1963), the times required for $50 \%$ and $95 \%$ mass loss were calculated as $T_{50}=1 / k$ and $T_{95}=31$ $k$, respectively.

For each sampling, the remaining litter mass, C, N, P, K, Ca, Mg, S, Mn and Fe concentrations were expressed as percentages of the initial values $\left(P_{\mathrm{ii}}\right)$, according to the equation used by Baldantoni et al. (2013 - eqn. 2):

$$
P_{i j}=\frac{C_{i j} \cdot W_{i}}{C_{0 j} \cdot W_{0}} \cdot 100
$$

where $C_{0 j}$ is the initial concentration of the $j$-th parameter analysed, $W_{0}$ the initial litter weight, $C_{i j}$ is the concentration of the $j$-th parameter at the $i$-th sampling and $W_{i}$ is the litter weight at the $i$-th sampling.

\section{Statistical analysis}

Means and standard deviations of litter quality parameters and litter decomposition rates were calculated for each stand age class (4 age classes and 3 replicates per age class). A two-way ANOVA (analysis of variance) was applied to analyse the effects of the stand age classes and time on the initial litter quality parameters using the software SPSS ${ }^{\circledR}$ ver. 17.0 for Windows (IBM, Armonk, NY, USA). Following the re-

Tab. 1 - Stand and soil characteristics for per stand age classes. Means with different alphabets in rows indicate significant $(p<0.001)$ difference between the stand age classes.

\begin{tabular}{|lrrrr}
\hline \multirow{2}{*}{ Variable } & \multicolumn{3}{c}{ Stand age classes (years) } \\
\cline { 2 - 5 } & \multicolumn{1}{c}{ Fir $_{38}$} & \multicolumn{1}{c}{ Fir $_{60}$} & Fir $_{90}$ & \multicolumn{1}{c}{ Fir $_{100}$} \\
\hline Mean diameter (cm) & $30.8 \pm 1.4^{\mathrm{a}}$ & $41.5 \pm 3.9^{\mathrm{b}}$ & $47.0 \pm 3.0^{\mathrm{c}}$ & $48.0 \pm 2.4^{\mathrm{c}}$ \\
\hline Mean height (m) & $24 \pm 2.0^{\mathrm{a}}$ & $35 \pm 1.0^{\mathrm{b}}$ & $41 \pm 2.0^{\mathrm{c}}$ & $42 \pm 2.0^{\mathrm{c}}$ \\
\hline Canopy closure (\%) & $41-70$ & $41-70$ & $71-100$ & $71-100$ \\
\hline PH $\left(\mathrm{H}_{2} \mathrm{O}\right)$ & $5.16 \pm 0.14^{\mathrm{a}}$ & $5.15 \pm 0.30^{\mathrm{a}}$ & $5.99 \pm 0.37^{\mathrm{b}}$ & $5.00 \pm 0.23^{\mathrm{a}}$ \\
\hline Sand (\%) & $32 \pm 3.0^{\mathrm{b}}$ & $8 \pm 1.0^{\mathrm{a}}$ & $84 \pm 3.0^{\mathrm{c}}$ & $76 \pm 3.0^{\mathrm{c}}$ \\
\hline Clay (\%) & $42 \pm 3.05^{\mathrm{b}}$ & $54 \pm 2.0^{\mathrm{c}}$ & $8 \pm 1.0^{\mathrm{a}}$ & $9 \pm 1.0^{\mathrm{a}}$ \\
\hline Silt (\%) & $26 \pm 0.58^{\mathrm{c}}$ & $38 \pm 3.0^{\mathrm{d}}$ & $8 \pm 4.0^{\mathrm{a}}$ & $15 \pm 2.0^{\mathrm{b}}$ \\
\hline Soil bulk density $\left(\mathrm{g} \mathrm{cm}^{-3}\right)$ & $1.12 \pm 0.08^{\mathrm{a}}$ & $1.16 \pm 0.28^{\mathrm{a}}$ & $1.04 \pm 0.35^{\mathrm{a}}$ & $1.20 \pm 0.35^{\mathrm{a}}$ \\
\hline
\end{tabular}

sults of the ANOVA, Tukey's HDS (Honestly Significant Difference) test $(\alpha=0.05)$ was used to compare multiple litter quality parameters at each litter sampling time among age classes. Repeated measures ANOVA (RMANOVA) was adopted to test the effects of stand age class, time and their interactions on the differences in the litter decomposition rates.

\section{Results}

Fir stands, soil characteristics and litter chemistry

Stand characteristics and some mineral soil properties of the fir stand age classes are shown in Tab. 1. In general, the older stands $\left(\mathrm{Fir}_{90}\right.$ and $\left.\mathrm{Fir}_{100}\right)$ had higher mean tree diameter, height, canopy closure and sand content and lower mean clay and silt contents than the younger stands $\left(\mathrm{Fir}_{38}\right.$ and $\mathrm{Fir}_{60}-$ Tab. 1). The $\mathrm{Fir}_{90}$ stand showed the highest soil $\mathrm{pH}(5.99 \pm 0.37)$ compared

Tab. 2 - Initial litter quality parameters from the 4 different fir stand age classes. Means with different alphabets in rows indicate significant $(p<0.001)$ difference

\begin{tabular}{|c|c|c|c|c|c|}
\hline \multirow{2}{*}{ Parameters } & \multirow{2}{*}{ Units } & \multicolumn{4}{|c|}{ Stand age classes (years) } \\
\hline & & $\mathrm{Fir}_{38}$ & $\mathrm{Fir}_{60}$ & $\mathrm{Fir}_{90}$ & Fir $_{100}$ \\
\hline$C$ & $(\%)$ & $50.4 \pm 1.7^{\mathrm{a}}$ & $53.5 \pm 1.9^{b}$ & $49.7 \pm 1.6^{a}$ & $53.2 \pm 1.0^{b}$ \\
\hline N & $(\%)$ & $1.49 \pm 0.1^{b}$ & $1.11 \pm 0.11^{\mathrm{a}}$ & $1.00 \pm 0.1^{\mathrm{a}}$ & $1.39 \pm 0.1^{b}$ \\
\hline Hemicellulose & $\mathrm{mg} \mathrm{g}^{-1}$ & $497 \pm 13.3^{\text {a }}$ & $465 \pm 12.0^{a}$ & $619 \pm 15.4^{b}$ & $464 \pm 6.0^{a}$ \\
\hline Cellulose & $\mathrm{mg} \mathrm{g}^{-1}$ & $644 \pm 6.0^{\mathrm{a}}$ & $729 \pm 1.0^{b}$ & $788 \pm 7.0^{b}$ & $670 \pm 2.0^{a}$ \\
\hline Lignin & $(\%)$ & $24 \pm 3.0^{b}$ & $14 \pm 1.0^{\mathrm{a}}$ & $18 \pm 4.0^{b}$ & $21 \pm 2.0^{b}$ \\
\hline $\mathrm{C}: \mathrm{N}$ & ratio & $34: 01: 00$ & 48:01:00 & 50:01:00 & $38: 01: 00$ \\
\hline L:N & ratio & $16: 01: 00$ & 13:01:00 & 18:01:00 & $15: 01: 00$ \\
\hline $\mathrm{Ca}$ & $\mathrm{mg} \mathrm{kg}^{-1}$ & $23,630 \pm 30^{a}$ & $20,500 \pm 20^{a}$ & $33,080 \pm 30^{b}$ & $32,470 \pm 30^{b}$ \\
\hline Mg & $\mathrm{mg} \mathrm{kg}^{-1}$ & $2185 \pm 21^{b}$ & $1235 \pm 15^{a}$ & $3034 \pm 25^{c}$ & $2113 \pm 21^{b}$ \\
\hline K & $\mathrm{mg} \mathrm{kg}^{-1}$ & $6065 \pm 15^{a}$ & $6221 \pm 15^{a}$ & $7184 \pm 16^{c}$ & $7838 \pm 17^{c}$ \\
\hline$P$ & $\mathrm{mg} \mathrm{kg}^{-1}$ & $1871 \pm 3^{c}$ & $1822 \pm 3^{b c}$ & $1780 \pm 3^{b}$ & $1570 \pm 3^{a}$ \\
\hline$S$ & $\mathrm{mg} \mathrm{kg}^{-1}$ & $2073 \pm 3^{b}$ & $2023 \pm 3^{b}$ & $2120 \pm 3^{b}$ & $1998 \pm 3^{b}$ \\
\hline Mn & $\mathrm{mg} \mathrm{kg}^{-1}$ & $2339 \pm 3^{c}$ & $3044 \pm 3^{d}$ & $458 \pm 1.3^{a}$ & $2024 \pm 3^{b}$ \\
\hline $\mathrm{Fe}$ & $\mathrm{mg} \mathrm{kg}^{-1}$ & $1068 \pm 3^{c}$ & $421 \pm 2.5^{a}$ & $489 \pm 2.1^{b}$ & $494 \pm 2.4^{b}$ \\
\hline
\end{tabular}
between the stand age classes. to the $\mathrm{F}_{38}, \mathrm{Fir}_{60}$ and $\mathrm{Fir}_{100}$ Stands, which had similar soil pH $(5.00 \pm 0.23,5.15 \pm 0.30$ and $5.16 \pm 0.14$, respectively). Soil bulk density, however, was similar in all fir stand age classes.

Initial litter parameters and the ratios of $\mathrm{C} / \mathrm{N}$ and lignin/ $\mathrm{N}$ in the needle litters are given in Tab. 2. The results showed that there were significant intraspecific variations $(p<0.001)$ in the chemical compositions of Kazdagi fir litters among the different stand age classes, which in turn affected their decomposition rates. Initial litter carbon concentrations in $\mathrm{Fir}_{60}$ and $\mathrm{Fir}_{100}$ stands were higher $(53.5 \% \pm 1.9 \%$ and $53.2 \%$ $\pm 1.0 \%$, respectively) than in $\mathrm{Fir}_{38}$ and $\mathrm{Fir}_{90}$ stands $(50.4 \% \pm 1.7 \%$ and $49.7 \% \pm 1.6 \%$, respectively). However, initial litter $\mathrm{N}$ and lignin concentrations in $\mathrm{Fir}_{60}$ and $\mathrm{Fir}_{90}$ stands (the middle-aged fir stands) were lower $(1.11 \% \pm 0.11 \%$ and $1.00 \% \pm 0.1 \%$ for $N, 14 \% \pm$ $1.0 \%$ and $18 \% \pm 4.0 \%$ for lignin, respectively) than in $\mathrm{Fir}_{38}$ and $\mathrm{Fir}_{100}$ stands $(1.49 \% \pm 0.1 \%$ 


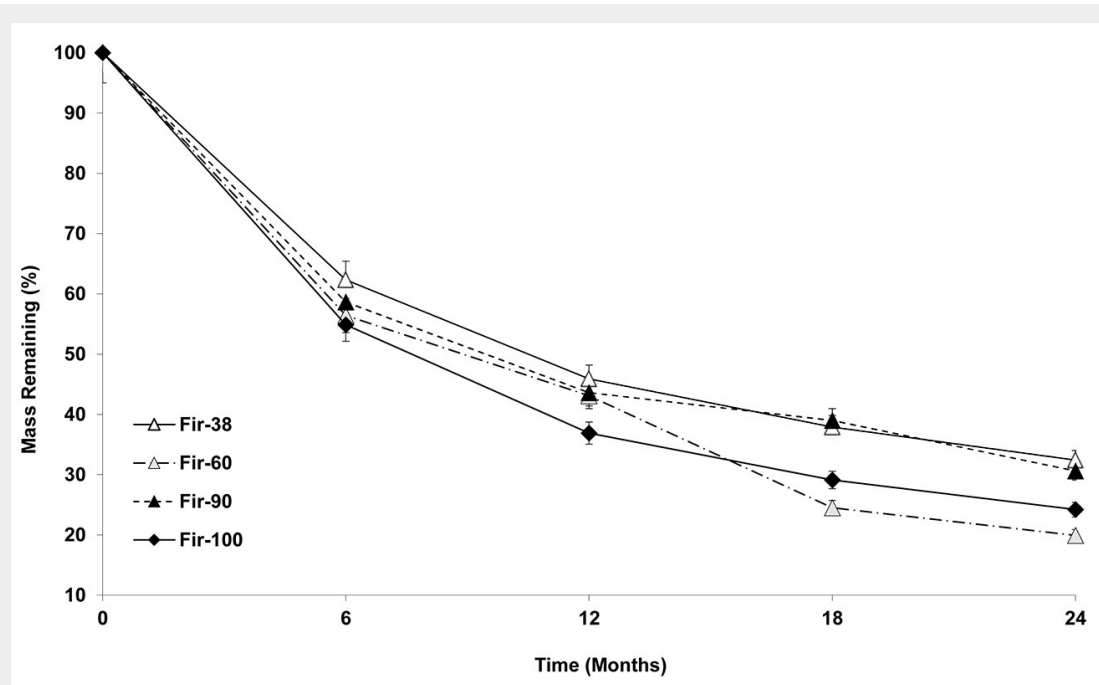

Fig. 2 - Mean mass loss of fir litters from the 4 different stand age classes.

and $1.39 \% \pm 0.1 \%$ for $\mathrm{N}, 24 \% \pm 3.0 \%$ and $21 \% \pm$ $2.0 \%$ for lignin, respectively).

The $\mathrm{Fir}_{90}$ stand had the highest litter cellulose and hemicellulose concentrations ( 788 \pm 7.0 and $619 \pm 15.4 \mathrm{mg} \mathrm{g}^{-1}$, respectively) compared to the other 3 age classes, which showed relatively similar hemicellulose concentrations ( $\left.465 \mathrm{mg} \mathrm{g}^{-1}\right)$; however, for cellulose concentration, age class order

was $\operatorname{Fir}_{60}\left(729 \pm 1.0 \mathrm{mg} \mathrm{g}^{-1}\right), \operatorname{Fir}_{100}(670 \pm 2.0$ $\left.\mathrm{mg} \mathrm{g}^{-1}\right)$ and $\mathrm{Fir}_{38}\left(644 \pm 6.0 \mathrm{mg} \mathrm{g}^{-1}-\right.$ Tab. 2). Initial litter $\mathrm{C} / \mathrm{N}$ ratios were higher in $\mathrm{Fir}_{60}$ and $\mathrm{Fir}_{90}$ (48:1 and 50:1, respectively) than in $\mathrm{Fir}_{38}$ and $\mathrm{Fir}_{100}$ (34:1 and 38:1, respectively). The $\mathrm{Fir}_{90}$ stands also had a higher initial litter lignin/ $N$ ratio (18:1) than the Fir $_{60}$ and Fir $_{100}$ stands (16:1 and 15:1, respectively). However, the $\mathrm{Fir}_{60}$ stands showed

Tab. 3 - Annual decomposition constant $(k)$ and the time (year) required for $50 \%\left[T_{50}\right.$ $(\mathrm{y})]$ and $95 \%$ mass loss $\left[\mathrm{T}_{95}(\mathrm{y})\right]$ under 4 different fir stand age classes.

\begin{tabular}{lcccc}
\hline \multirow{2}{*}{ Parameters } & \multicolumn{4}{c}{ Stand age classes (years) } \\
\cline { 2 - 5 } & $\mathrm{Fir}_{38}$ & $\mathrm{Fir}_{60}$ & $\mathrm{Fir}_{90}$ & $\mathrm{Fir}_{100}$ \\
\hline$k\left(\mathrm{yr}^{-1}\right)$ & -0.743 & -0.948 & -0.788 & -0.944 \\
$\mathrm{r}^{2}$ & 0.975 & 0.519 & 0.946 & 0.979 \\
$\mathrm{~F}$ & $\mathrm{p}<0.001$ & $\mathrm{p}<0.001$ & $\mathrm{p}<0.001$ & $\mathrm{p}<0.001$ \\
$\mathrm{~T}_{50}(\mathrm{y})$ & 1.35 & 1.05 & 1.27 & 1.06 \\
$\mathrm{~T}_{95}(\mathrm{y})$ & 4.04 & 3.16 & 3.81 & 3.18 \\
\hline
\end{tabular}

the lowest initial lignin/ $\mathrm{N}$ ratio (13:1). In general, the middle-age fir stands $\left(\mathrm{Fir}_{60}\right.$ and $\mathrm{Fir}_{90}$ ) had lower $\mathrm{N}$ and lignin concentrations but higher cellulose concentrations and $\mathrm{Cl}$ $\mathrm{N}$ ratios compared to the younger $\left(\mathrm{Fir}_{38}\right)$ and older ( Fir $_{100}$ ) fir stands (Tab. 2).

Overall, initial litter $\mathrm{Ca}, \mathrm{Mg}$ and $\mathrm{K}$ concentrations were higher in the older fir stands $\left(\mathrm{Fir}_{90}\right.$ and $\mathrm{Fir}_{100}$ ) than in the younger fir stands $\left(\mathrm{Fir}_{38}\right.$ and $\mathrm{Fir}_{60}-$ Tab. 2). Initial litter, $\mathrm{P}$ and $\mathrm{Mn}$ concentrations, however, were lower in the older fir stands than in the younger fir stands. Initial Fe concentration was highest in the youngest fir stand $\left(F_{38}\right)$ as compared to the other fir stands, which had similar Fe concentrations (Tab. 2). Initial litter $\mathrm{S}$ concentration did not vary among the fir stand age classes.

\section{Needle litter mass losses}

Fig. 2 shows the remaining mass of the fir needle litter in the four different stand age classes over 24 months. According to the ANOVA results, the main effects of time and the interaction of time and stand age on mass loss were all significant $(p<0.001)$. These results demonstrate that litter mass losses of fir varied significantly between the sampling times and between the fir stand age classes.

After 6 months, the needle litters in $\mathrm{Fir}_{100}$ and $\mathrm{Fir}_{60}$ stands showed higher mean mass losses ( $45 \%$ and $44 \%$, respectively) than in $\mathrm{Fir}_{90}$ and $\mathrm{Fir}_{38}$ (41\% and 38\%, respectively). There was a $7 \%$ difference in needle-mass losses between the oldest and youngest stands. At 12 months, the needle litter under Fir $_{100}$ still had the highest mass losses (63\%), while $\mathrm{Fir}_{38}$ had the lowest (54\%). The needle litters had similar mass loss under $\mathrm{Fir}_{60}(57 \%)$ and $\mathrm{Fir}_{90}(57 \%)$. The differences in needle mass losses between the oldest and the youngest stands were higher at 12 months (by 9\%) than at 6 months. At 18 months, the needle litters under $\mathrm{Fir}_{60}$ de-
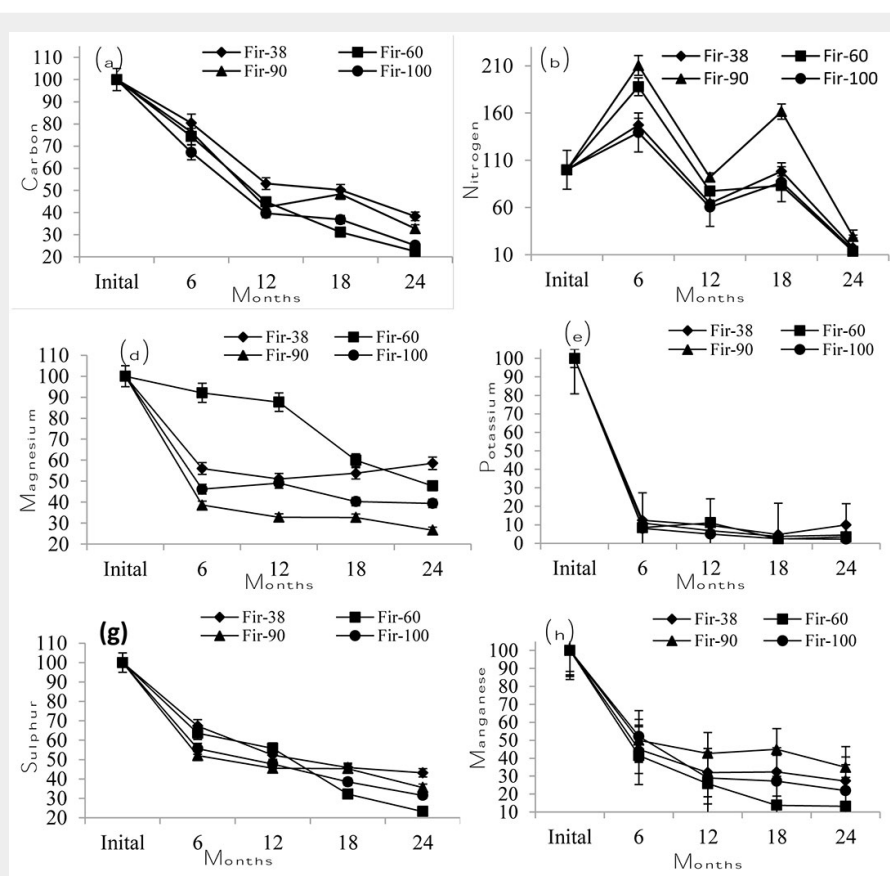
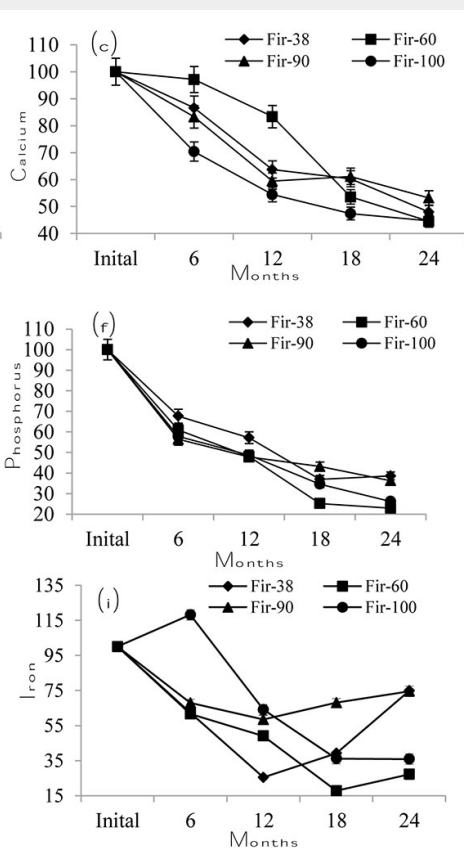

Fig. 3 - Variation in total C (a), N (b), Ca (c), Mg (d), K (e), P (f), S (g), Mn (h) and $\mathrm{Fe}$ (i) concentrations in fir litters during decomposition period ( 24 months) from the 4 different stand age classes. 
composed much faster and had the highest values $\left(76 \%\right.$ ), followed by $\mathrm{Fir}_{100}(71 \%), \mathrm{Fir}_{90}$ and $\mathrm{Fir}_{38}$, which had the same mass losses (62\%). The differences in the needle mass losses between the oldest and the young est stands at 18 months were much higher (14\%). At 24 months, the needle litters under $\mathrm{Fir}_{60}$ had the highest mass loss $(80 \%)$ followed by $\mathrm{Fir}_{100}(76 \%), \mathrm{Fir}_{90}(69 \%)$ and $\mathrm{Fir}_{38}$ (68\%). The differences in the needle mass losses between the oldest and the youngest stands at 24 months were still higher (12\%).

Decay rates $(\mathrm{k})$ and the time required fo $50 \%\left[T_{50}(y)\right]$ and $95 \%$ mass loss $\left[T_{95}(y)\right]$ for the needle litters from the different stand age classes are given in Tab. 3. The decay rates of the needle litters were higher in Fir $_{60}$ and Fir $_{100}$ stands (-0.948 and -0.944, re spectively) than in $\mathrm{Fir}_{38}$ and $\mathrm{Fir}_{90}$ stands (-0.743 and -0.788 , respectively). The calcu lated times required for $50 \%$ mass loss were higher in $\mathrm{Fir}_{38}(1.35 \mathrm{y})$ and $\mathrm{Fir}_{90}(1.27 \mathrm{y})$ than in $\operatorname{Fir}_{100}(1.06 \mathrm{y})$ and $\mathrm{Fir}_{60}(1.05 \mathrm{y})$. A similar order was seen for the time required for $95 \%$ mass loss, indicating that the needle litters under $\mathrm{Fir}_{38}$ and $\mathrm{Fir}_{90}$ need approximately 4 years to lose $95 \%$ of mass com pared to the needle litters under $\mathrm{Fir}_{60}$ and Fir $_{100}$, which need less time $(\sim 3 \mathrm{y})$.

Initial litter C, P, K, Mg, Ca, S, Mn and $\mathrm{Fe}$ concentrations all decreased over time (Fig. 3). Initial $\mathrm{N}$ concentration also decreased over time but had two peaks at the 6-month and 18-month intervals (Fig. $3 \mathrm{~b})$. The needle litters in the middle age stands $\left(\mathrm{Fir}_{60}\right.$ and $\left.\mathrm{Fir}_{90}\right)$ had higher peaks than $\mathrm{Fir}_{38}$ and $\mathrm{Fir}_{100}$. At the 12-month and 24month intervals, $\mathrm{N}$ concentration in the needle litters decreased. Initial C, P and S concentrations decreased linearly and did not show any significant differences among the fir stand age classes (Fig. $3 a$ Fig. $3 \mathrm{f}$ and Fig. 3g, respectively). Initial $\mathrm{K}$ concentration showed a sharp decrease at the 6-month interval but remained relatively stable after that (Fig. 3e). Initial $\mathrm{Ca}$, $\mathrm{Mn}$ and Fe concentrations also decreased over time but varied among the fir stand age classes (Fig. 3c, Fig. 3h and Fig. 3i, re spectively).

\section{Discussion}

\section{Variation in fir litter quality with stand} age classes

In temperate ecosystems, initial litte quality parameters (mainly lignin and nitro gen concentration) largely influence litter decomposition rates, which in turn influences the turnover of associated carbon and nutrients as a dominant source of or ganic matter input to the soil (Melillo et al. 1982, Aerts 1997). Initial litter quality also affects nitrogen availability for plants and soil N dynamics (Hobbie 2000). Many studies have shown that higher litter $\mathrm{C} / \mathrm{N}$ and lignin/ $\mathrm{N}$ ratios are associated with slow rates of net soil $\mathrm{N}$ mineralization (Scott \& Binkley 1997, Satti et al. 2003). The specific quality of the litter that plants produce is, therefore, a key trait for the functioning of ecosystems (Trap et al. 2013).

To our knowledge, no study has directly investigated the forest stand age-related variability in litter quality of Kazdagi fir (Abies nordmanniana subsp. equi-trojani [Steven] Spach) and its consequences for litter decomposition processes. Our results indicated that initial $\mathrm{N}$ and lignin concentration in fir needle litter was lower in the middle-age fir stands compared to the younger- and older-age fir stands. Similar findings were also reported by Inagaki et al. (2004) who found that $\mathrm{N}$ and lignin concentrations in leaf litter were lower in middle-aged forests than in young forests. The authors state that in the middle-aged forests, tree density decreases due to thinning practices or competition among individuals; and the $\mathrm{N}$ capital in the biomass increases, especially for evergreen species, indicating that $\mathrm{N}$ becomes a less limiting resource. They concluded that changes in $\mathrm{N}$ demand for plants are likely a major factor affecting lignin production in leaf litter. In contrast to those findings, Trap et al. (2013) who studied pure beech (Fagus sylvatica) forest stands differing in age (15, 65, 95 and 130 years) found that lignin and lignin/ $\mathrm{N}$ ratios were highest in stands of intermediate age.

In the present study, significant differences were evident in nutrient concentrations among the age classes of the fir stands; however, the differences did not clearly show a linear increase or decrease pattern with the stand age classes. Other researchers have also stated that the effect of the nutrient concentrations on litter due to stand age was not continuous (Welke \& Hope 2005). Trap et al. (2013) found significantly high $\mathrm{Mg}, \mathrm{N}$ and $\mathrm{K}$ litter concentrations in 15-year-old stands of pure beech that subsequently decreased with increasing stand age; $M n$, on the other hand, was the only nutrient analysed that was highest in the oldest stands. They attributed the observed differences among stands of different ages to (i) the relative abundance of sun and shade leaves and (ii) increasing intraspecific competition for soil nutrients with increasing tree age (Ryan et al. 1997).

\section{Variation in initial litter quality} parameters among fir subspecies

The initial litter $C$ and $N$ concentrations of Abies nordmanniana subsp. equi-trojani were partly comparable with the findings of other studies and occasionally lower or higher than their results depending on the fir subspecies used in their studies. Wei et al. (2020) found that initial $C$ concentration for Abies fabri was $51.3 \%$, which was similar to the initial litter C concentration (51.7\%) for Abies nordmanniana subsp. equi-trojani. Jagodzinski et al. (2019) studied Abies alba stands ranging from 8-115 years old (12 different aged tree stands) in southern Poland and found that $\mathrm{C}$ concentration ranged from $50.4 \%$ (8 years old) to $52.7 \%$ (93 years old). A study by Wu et al. (2014) showed that initial carbon and $\mathrm{N}$ concentrations of Abies faxoniana were $52 \%$ and $1.12 \%$, respectively. Similarly, in a study of Abies faxoniana tree stands in western Sichuan, China, Wu et al. (2010) found that initial $\mathrm{C}$ and $\mathrm{N}$ values were $51.6 \%$ and $0.92 \%$, respectively. Sariyildiz et al. (2005) reported that for Abies nordmanniana subsp. bornmuelleriana Maltfelt, initial litter was $47 \%$ C and $1.10 \%$ N. Accordingly, Abies nordmanniana subsp. equi-trojani had lower initial litter lignin concentrations (from $14 \%$ to $24 \%$ ) than the litters of Abies alba (mean $30.5 \%$ ) and Abies nordmanniana subsp. bornmuelleriana (mean 36\%) but similar values with the litter of Abies faxoniana (mean $25 \%)$.

Initial litter hemicellulose and cellulose concentrations of Abies nordmanniana subsp. equi-trojani were much higher than the values reported for Abies alba (Hobbie et al. 2006), which were $199.9 \mathrm{mg} \mathrm{g}^{-1}$ for cellulose and $123.4 \mathrm{mg} \mathrm{g}^{-1}$ for hemicellulose. The same was true for Abies nordmanniana subsp. bornmuelleriana Maltfelt, which had initial litter cellulose concentrations between $260 \mathrm{mg} \mathrm{g}^{-1}$ and $290 \mathrm{mg} \mathrm{g}^{-1}$ (Sariyildiz et al. 2005). Palosuo et al. (2005) found $416 \mathrm{mg}$ $\mathrm{g}^{-1}$ for initial cellulose and $303 \mathrm{mg} \mathrm{g}^{-1}$ for initial lignin in Douglas-fir (Pseudotsuga menziesii [Mirb.] Franco) stands. Wu et al. (2010) noted that initial lignin and cellulose concentrations for Abies faxoniana trees were $418.3 \mathrm{mg} \mathrm{g}^{-1}$ and $294.5 \mathrm{mg} \mathrm{g}^{-1}$, respectively. Mean $\mathrm{C} / \mathrm{N}$ ratios in the litters of Abies nordmanniana subsp. equi-trojani (from 34:1 to 50:1) were similar to the litter of Abies nordmanniana subsp. bornmuelleriana Maltfelt, ranging from 38:1 to 51:1. However, mean lignin/ $\mathrm{N}$ ratios were lower in the litters of Abies nordmanniana subsp. equi-trojani (from 13:1 to 18:1) than in the litter of Abies nordmanniana subsp. bornmuelleriana Maltfelt, ranging from 25:1 to 45:1. Palosuo et al. (2005) found that $\mathrm{C} / \mathrm{N}$ ratios and lignin/ $\mathrm{N}$ for Douglas-fir were 56:1 and 45:1, respectively.

When comparing the findings of other studies with the initial litter $\mathrm{P}$ and $\mathrm{K}$ concentrations found in the present study, our values are higher than the values found for Abies alba (Hobbie et al. 2006), which were $1180 \mathrm{mg} \mathrm{g}^{-1}$ for $\mathrm{P}$ and $2200 \mathrm{mg} \mathrm{g}^{-1}$ for K. Our initial $\mathrm{Ca}$ and $\mathrm{Mg}$ concentrations were also much higher than the values found for Abies alba (Hobbie et al. 2006), which were $12,400 \mathrm{mg} \mathrm{g}^{-1}$ for $\mathrm{Ca}$ and $800 \mathrm{mg} \mathrm{g}^{-1}$ for $\mathrm{Mg}$.

\section{Variation in mass losses with stand age} classes

Our results indicate that decomposition rate did not vary monotonically with the increase in stand age of fir. Needle litters under $\mathrm{Fir}_{100}$ and $\mathrm{Fir}_{60}$ stands decomposed faster than the needle litters under $\mathrm{Fir}_{90}$ and $\mathrm{Fir}_{38}$ stands. The faster rate of litter decomposition in $\mathrm{Fir}_{60}$ and $\mathrm{Fir}_{100}$ stands noted in the present study was associated with a lower value of lignin/ $\mathrm{N}$ ratio (13:1 and 15:1, respectively) in the litter samples compared to $\mathrm{Fir}_{38}$ and $\mathrm{Fir}_{90}$ (16:1 and 18:1, re- 
spectively). It is generally argued that decomposition is relatively faster with litter of lower lignin content and in sites with a warm and humid climate; dry, wet and cold climates and poor litter quality would inhibit litter decomposition processes (Laskowski \& Berg 2006, Berg et al. 2010, Currie et al. 2010). Several studies have also reported significant correlations between lignin content or the lignin/ $\mathrm{N}$ ratio and decay rates for a variety of litter types (Fogel \& Cromack 1977, Berendse et al. 1987, Sariyildiz 2015). For example, Melillo et al. (1982) found strong, negative, linear relationships between initial lignin/ $\mathrm{N}$ ratios and mass-loss rates of leaf litter from northern hardwoods and other areas. The conditions for microorganisms were possibly more favourable in $\mathrm{Fir}_{100}$ and $\mathrm{Fir}_{60}$ stands than $\mathrm{Fir}_{90}$ and $\mathrm{Fir}_{38}$ stands, resulting in the higher litter decomposition rates. Because lignin is a resistant substrate, more time is required for microbial decomposition; therefore, organic substances with large amounts of lignin decompose over longer periods (Sariyildiz 2000). The lignin content was highest in $\mathrm{Fir}_{38}$ and lowest in $\mathrm{Fir}_{60}$, which may have affected litter decomposition. Long-term climate changes have the greatest effect on litter decomposition and carbon sinks. Such changes are not only related to temperature changes, but to seasonal precipitation changes as well, which can be more influential (Klopatek 2008). Similarly, Fogel \& Cromack (1977) stated that the rapid decomposition of litter was due to excessive temperature differences (especially since it affects the water-soil regime), and that the mass-loss rate of coniferous species significantly affected the mass.

On the other hand, age-related forest stand changes in forest structure influence the quality and quantity of organic matter input and thus nutrient turnover (Inagaki et al. 2004, Trap et al. 2009). Additionally, structural changes of the canopy layer during succession can also affect the microclimate on the forest floor due to alterations in solar radiation, wind speed or rainfall interception (Chen et al. 1999, Shen et al. 2012). As shown by other studies, forest development over time can result in substantial changes in fir stand conditions, especially microclimate factors (Aerts 1997), soil fauna (Chauvat et al. 2009), soil microbial community composition (Smithwick et al. 2005) and nutrient cycling efficiency (Trap et al. 2009), which are seen as the most influential factors on litter mass loss.

Other studies using fir or different tree species have also found contrasting results with litter mass losses related to stand age. Klaus (2018) noted that the litter decomposition rates for balsam fir (Abies balsamea) and white spruce (Picea glauca) needles increased slightly with increasing stand age. Welke \& Hope (2005) studied Douglas-fir (Pseudotsuga menziesii) and paper birch (Betula papyrifera) aged 10-25, 50-65 and $>85$ years old and found that Douglas fir lit- ter decayed more in old stands than in younger stands, while the opposite trend was seen for birch litter. Yu et al. (2014) assessed four Chinese fir plantations $(7,16,23$ and 29 years old) and found that litter decomposition rates decreased between the 7- and 16-year-old plantations, then significantly increased from the 16- to 23-year-old plantations and reached a peak in the 29year-old plantations. Trogisch et al. (2016) found that litter decomposition declined with forest stand age. Their results clearly showed that microclimatic site conditions were more favourable for litter decomposition in young forest stands. A study by Brun et al. (2008) also showed that Scots pine needles in the 118-year-old stands decayed less than in the 70- and 53-year-old stands. Sharma \& Ambasht (1987) found that $\mathrm{T}_{1 / 2}$ value for Alnus nepalensis mass was lowest in the 30-year stand and highest in the 56-year stand, indicating that mass loss was much faster in the 30-year stand.

\section{Variation in mass losses and nutrients during litter decomposition}

As demonstrated by several authors (Sariyildiz \& Anderson 2003a, Pérez-Suárez et al. 2012), the general trend in litter decomposition processes is initially rapid and then slows down. A similar trend was also seen in our study for fir litter decomposition (Fig. 2). The litters of $\mathrm{Fir}_{38}, \mathrm{Fir}_{60}, \mathrm{Fir}_{90}$ and Fir $_{100}$ respectively lost $54 \%, 57 \%, 57 \%$ and $63 \%$ of their initial weight in the first year (0-12 months) compared with $14 \%, 23 \%, 12 \%$ and $13 \%$ losses in the second year (12-24 months). Initially, accelerated litter decomposition rates are mainly attributed to easier degradation of water-soluble organic compounds, while the later, slower litter decomposition rates are mostly due to difficulties in microbial degradation and mineralization of chemically recalcitrant complex compounds, such as polyphenols and lignin. Researchers have shown that litter $\mathrm{N}$ concentration has a strong, positive influence on initial litter decay (<3 months), as higher concentration of this element is associated with faster decomposition rates, while lignin and $\mathrm{C} / \mathrm{N}$ ratios determine later rates of decomposition (Aber et al. 1990).

Mean mass loss in the fir stands was $58 \%$ after 12 months and $74 \%$ after 24 months. These values were much higher than the values shown by Sariyildiz \& Küçük (2008) for fir (31\% and $52 \%$, respectively). Wei et al. (2020) noted that throughout the experiment, the dry weight loss rate of fir litter was $32 \%$. The decay-rate coefficients $(k)$ for fir litters (ranging from -0.743 to -0.948 in this study) were comparatively higher than the $-0.370 k$ value reported by Sariyildiz \& Küçük (2008). Klaus (2018) noted that the decay-rate coefficients $(k)$ for balsam fir aged $1,13,16,28$ and 29 years were -0.26 , $-0.34,-0.31,-0.35$ and -0.36 , respectively, after 12 months.

Research suggests that nutrient concentrations vary to some extent during the de- composition period. An increase in litter $\mathrm{N}$ concentration (Fig. 3b) followed by a decline over time, as observed in this study, is similar to the patterns found in other studies (Bubb et al. 1998, Singh et al. 1999). Increases in $\mathrm{N}$ concentration could be attributed to the addition of $\mathrm{N}$ from exogenous sources to microbial biomass (Melillo et al. 1982, Sinsabaugh et al. 1993). Among the nutrients, initial litter $\mathrm{K}$ and $\mathrm{Mn}$ (Fig. $3 \mathrm{e}$ and Fig. 3 h, respectively) were lost from the decomposing litter mostly during the first 6 months. This indicates an initial leaching loss of $K$ because of its solubility. The relative elemental transfer from the decomposing litter generally demonstrates that potassium is highly mobile and nitrogen is the least mobile $(\mathrm{K}>\mathrm{Ca}>\mathrm{P}>\mathrm{N})$. The results of Laskowski et al. (1995a, 1995b) revealed an initial rapid decrease in $\mathrm{K}$ concentration followed by stabilisation or a slow increase. Similarly, Brais et al. (1995) demonstrated for Abies balsamea that K, Ca and $\mathrm{Mg}$ concentrations decreased with time. Gosz et al. (1973) reported an increase in absolute phosphorus content in deciduous litter during the first year of decomposition. However, Edmonds (1980) found that phosphorus was rapidly lost in the first three months, and absolute weights never exceeded initial weights in A. rubra and $A$. nepalensis litter. Sharma \& Ambasht (1987) demonstrated that the 30-year stand had a higher rate of phosphorus loss than the other stands, while the 56-year stand had the lowest rate. We did not study the differences in soil nutrient status and microclimate conditions of the different stand age classes of the fir species; however, the results indicate that those factors should be taken into account to fully understand the differences in the decomposition process among the different stand age classes.

\section{Conclusion}

Our results indicate that forest stand age is an important driver of intraspecific variability in fir litter quality parameters and decomposition rates with associated consequences for ecosystem functioning. The decomposition rate did not vary monotonically with increases in fir stand age. However, the results have clearly shown that the faster decomposition rates in $\mathrm{Fir}_{60}$ and $\mathrm{Fir}_{100}$ stands are associated with a lower value of lignin/ $\mathrm{N}$ ratio in the litter samples compared to $\mathrm{Fir}_{38}$ and $\mathrm{Fir}_{90}$ stands. Unfortunately, these forest age-related intraspecific variations in litter quality and mass losses are unprecedented and largely unexplained. There is clearly a need for further studies focusing on those topics, their variation and their potential driving forces on soil processes.

\section{Acknowledgements}

This research has been supported by the Scientific Research Projects Coordination Department of the Kastamonu University (KUBAP), Turkey (Project no. KUBAP-032015-01). 


\section{References}

Aber JD, Melillo JM, McClaugherty CA (1990). Predicting long term pattern of mass loss, nitrogen dynamics and soil organic matter formation from fine litter chemistry in temperate forest ecosystems. Canadian Journal of Botany 68: 2201-2269. - doi: 10.1139/b9o-287

Aerts R (1997). Climate, leaf litter chemistry and leaf litter decomposition in terrestrial ecosystems: a triangular relationship. Oikos 79: 439449. - doi: $10.2307 / 3546886$

Albert $\mathrm{CH}$, Thuiller W, Yoccoz NG, Soudant A, Boucher F, Saccone P, Lavorel S (2010). Intraspecific functional variability: extent, structure and sources of variation. Journal of Ecology 98: 604-613. - doi: 10.1111/j.1365-2745.2010.01651.x

Allen SE (1989). Chemical analysis of ecological materials. Blackwell Scientific Publications. Oxford, London, pp. 368.

Baldantoni D, Bellino A, Manes F, Alfani A (2013). Ozone fumigation of Quercus ilex L. slows down leaf litter decomposition with no detectable change in leaf composition. Annals of Forest Science 70: 571-578. - doi: 10.1007/s13595013-0297-5

Berendse F, Berg B, Bosatta E (1987). The effect of lignin and nitrogen on the decomposition of litter in nutrient-poor ecosystems: a theoretical approach. Canadian Journal of Botany 65: 11161120. - doi: 10.1139/b87-155

Berg B, De Marco A, Davey M, Emmett B, Hobbie $S$, Liu C, McClaugherty C, Norell L, Johansson M-B, Rutigliano F, Vesterdal L, Virzo De Santo A (2010). Limit values for foliar litter decomposition - pine forests. Biogeochemistry 100: 57-73. doi: 10.1007/s10533-009-9404-y

Berg B, Meentemeyer V (2002). Litter quality in European transect versus carbon storage potential. Plant and Soil 242 (1): 83-92. - doi: 10.10 23/A:1019637807021

Bocock KL, Gilbert OJ (1957). The disappearance of litter under different woodland conditions. Plant and Soil 9: 179-185. - doi: 10.1007/BF01398 924

Bouyoucos GJ (1962). Hydrometer method improved for making particle size analyses of soils. Agronomy Journal 54: 595-622. - doi: 10.21 34/agronj1962.00021962005400050028x

Brais S, Camiré C, Bergeron Y, Paré D (1995). Changes in nutrient availability and forest floor characteristics in relation to stand age and forest composition in the southern part of the boreal forest of northwestern Quebec. Forest Ecology and Management 76 (1-3): 181-189. doi: 10.1016/0378-1127(95)03541-H

Brun $C B$, Aström ME, Peltola $P$, Johansson $M B$ (2008). Trends in major and trace elements in decomposing needle litters during a long-term experiment in Swedish forests. Plant and Soil 306 (1-2): 199-210. - doi: 10.1007/s11104-008-95 $72-x$

Bubb KA, Xu ZH, Simpson JA, Saffigna PG (1998). Some nutrient dynamics associated with litterfall and litter decomposition in hoop pine plantations of southeast Queensland, Australia. Forest Ecology and Management 110 (1-3): 343352. - doi: 10.1016/S0378-1127(98)00295-3

Carreiro MM, Howe K, Parkhurst DF, Pouyat RV (1999). Variation in quality and decomposability of red oak leaf litter along an urban-rural gradient. Biology and Fertility of Soils 30: 258-268. doi: 10.1007/s003740050617

Chauvat M, Zaitsev AS, Gabriel E, Wolters V (2009). How do soil fauna and soil microbiota respond to beech forest growth? Current Zoology 55 (4): 272-278. - doi: 10.1093/czoolo/55.4.2 72

Chen J, Saunders SC, Crow TR, Naiman RJ, Brosofske KD, Mroz GD, Brookshire BL, Franklin JF (1999). Microclimate in forest ecosystem and landscape ecology: variations in local climate can be used to monitor and compare the effects of different management regimes. BioScience 49 (4): 288-297. - doi: 10.2307/1313612 Couteaux MM, Bottner P, Berg B (1995). Litter decomposition, climate and litter quality. Trends in Ecology and Evolution 10: 63-66. - doi: 10.1016/S0169-5347(00)88978-8

Currie WS, Harmon ME, Burke IC, Hart C, Parton JW, Silver W (2010). Cross-biome transplants of plant litter show decomposition models extend to a broader climatic range but lose predictability at the decadal time scale. Global Change Biology 16 (6): 1744-1761. - doi: 10.1111/j.1365-2486. 2009.02086.x

Edmonds RL (1980). Litter decomposition and nutrient release in Douglas-fir, red alder, western hemlock, and Pacific silver fir ecosystems in western Washington. Canadian Journal of Forest Research 10 (3): 327-337. - doi: 10.1139/x80056

Fogel R, Cromack JRK (1977). Effect of habitat and substrate quality on Douglas fir litter decomposition in western Oregon. Canadian Journal of Botany 55 (12): 1632-1640. - doi: 10.1139/b 77-190

Gosz JR, Likens GE, Bormann FH (1973). Nutrient release from decomposing leaf and branch litter in the Hubbard Brook Forest, New Hampshire. Ecological Monographs 43 (2): 173-191. doi: $10.2307 / 1942193$

Hättenschwiler S, Hagerman AE, Vitousek PM (2003). Polyphenols in litter from tropical montane forests across a wide range in soil fertility. Biogeochemistry 64 (1): 129-148. - doi: 10.1023/ A:1024966026225

Heal OW, Anderson JM, Swift MJ (1997). Plant litter quality and decomposition: an historical overview. In: "Driven by Nature: Plant Litter Quality and Decomposition" (Cadisch G, Giller KE eds). CAB International, Wallingford, UK, pp. 3-45.

Hobbie SE (2000). Interactions between litter lignin and soil nitrogen availability during leaf litter decomposition in a Hawaiian Montane forest. Ecosystems 3 (5): 484-494. - doi: 10.100 7/s100210000042

Hobbie SE, Reich PB, Oleksyn J, Ogdahl M, Zytkowiak R, Hale C, Karolewski P (2006). Tree species effects on decomposition and forest floor dynamics in a common garden. Ecology 87 (9): 2288-2297. - doi: 10.1890/0012-9658(200 6) 87 [2288:TSEODA]2.0.CO;2

Inagaki Y, Miura S, Kohzu A (2004). Effects of forest type and stand age on litterfall quality and soil $\mathrm{N}$ dynamics in Shikoku district, southern Japan. Forest Ecology and Management 202: 107-117. - doi: 10.1016/j.foreco.2004.07.029 Jackson ML (1962). Soil chemical analysis. Constable \& Co. Ltd, London, UK, pp. 42-47.

Jagodzinski AM, Dyderski MK, Gesikiewicz K, Horodecki P (2019). Tree and stand level esti- mations of Abies alba Mill. aboveground biomass. Annals of Forest Science 76 (2): 56. - doi: 10.1007/s13595-019-0842-y

Joly FX, Milcu A, Scherer-Lorenzen M, Jean LK, Bussotti F, Dawud SM, Müller S, Pollastrini M, Raulund-Rasmussen K, Vesterdal L, Hättenschwiler $S$ (2017). Tree species diversity affects decomposition through modified micro-environmental conditions across European forests. New Phytologist 214 (3): 1281-1293. - doi: 10.1111/ nph.14452

Klaus JA (2018). Influence of stand age, micro-climate, and litter composition on the decomposition of ten litter types in white spruce plantation forests in Nova Scotia, Canada. MSc thesis, Dalhousie University Halifax, Nova Scotia, Canada, pp. 180. [online] URL: http://dalspace. library.dal.ca/handle/10222/74086

Klopatek JM (2008). Litter decomposition contrasts in second-and old-growth Douglas-fir forests of the Pacific Northwest, USA. Plant Ecology 196 (1): 123-133. - doi: 10.1007/s11258-00 7-9339-0

Laskowski R, Berg B (2006). Litter decomposition: guide to carbon and nutrient turnover. Advances in Ecological Research, Amsterdam, Netherlands, pp. 428. [online] URL: http://ruj.uj. edu.pl/xmlui/handle/item/2770

Laskowski R, Berg B, Johansson MB, McClaugherty $C$ (1995b). Release pattern for potassium from decomposing forest needle and leaf litter. Long-term decomposition in a Scots pine forest. IX. Canadian Journal of Botany 73 (12): 2019-2027. - doi: 10.1139/b95-216

Laskowski R, Niklinska M, Maryanski M (1995a). The dynamics of chemical elements in forest litter. Ecology 76 (5): 1393-1406. - doi: 10.2307/19 38143

Lohbeck M, Poorter L, Martínez-Ramos M, Rodriguez-Velázquez J, Breugel $\mathrm{M}$, Bongers $\mathrm{F}$ (2014). Changing drivers of species dominance during tropical forest succession. Functional Ecology 28 (4): 1052-1058. - doi: 10.1111/1365-243 5.12240

Mataraci T (2012). Pinaceae. In: “Türkiye Bitkileri Listesi (Damarli Bitkiler) [Checklist of the Flora of Turkey (Vascular Plants)]" (Güner A, Aslan S, Ekim T, Vural M, Babaç MT eds). Research Association Press, Nezahat Gökyigit Botanical Garden and Flora, Istanbul, Turkey, pp. 14-17. [in Turkish]

Melillo JM, Aber J, Muratore JF (1982). Nitrogen and lignin control of hardwood leaf litter decomposition dynamics. Ecology 63 (3): 621-626. - doi: 10.2307/1936780

Olson JS (1963). Energy storage and the balance of producers and decomposers in ecological systems. Ecology 44 (2): 322-331. - doi: 10.2307/ 1932179

Palosuo T, Liski J, Trofymow JA, Titus BD (2005). Litter decomposition affected by climate and litter quality-testing the Yasso model with litterbag data from the Canadian intersite decomposition experiment. Ecological Modelling 189 (1-2): 183-198. - doi: 10.1016/j.ecolmodel.2005.03. 006

Pérez-Suárez M, Arredondo-Moreno JT, HuberSannwald E (2012). Early stage of single and mixed leaf-litter decomposition in semiarid forest pine-oak: the role of rainfall and microsite. Biogeochemistry 108: 245-258. - doi: 10.1007/s10 
533-011-9594-y

Rowland AP, Roberts JD (1994). Lignin and cellulose fractionation in decomposition studies using Acid Detergent Fibre methods. Communications in Soil Science and Plant Analysis 25: 269277. - doi: 10.1080/00103629409369035

Ryan MG, Binkley D, Fownes JH (1997). Age-related decline in forest productivity: pattern and processes. Advances in Ecological Research 27: 213-262. - doi: 10.1016/S0065-2504(08)60009-4

Sanger $L$, Cox P, Splatt P, Whelan M, Anderson JM (1998). Variability in the quality and potential decomposability of Pinus sylvestris litter from sites with different soil characteristics: acid detergent fibre (ADF) and carbohydrate signatures. Soil Biology and Biochemistry 30 (4): 455-461. - doi: 10.1016/Soo38-0717(97)0019 3-4

Sariyildiz T (2000). Biochemical and environmental controls of litter decomposition. PhD thesis, University of Exeter, UK, pp. 257.

Sariyildiz T (2015). Effects of tree species and topography on fine and small root decomposition rates of three common tree species (Alnus glutinosa, Picea orientalis and Pinus sylvestris) in Turkey. Forest Ecology and Management 335: 71-86. - doi: 10.1016/j.foreco.2014.09.030

Sariyildiz T, Anderson JM (2003a). Interactions between litter quality, decomposition and soil fertility: a laboratory study. Soil Biology and Biochemistry 35 (3): 391-399. - doi: 10.1016/So03 8-0717(02)00290-0

Sariyildiz T, Anderson JM (2003b). Decomposition of sun and shade leaves from three deciduous tree species, as affected by their chemical composition. Biology and Fertility of Soils 37 (3): 137-146. - doi: 10.1007/s00374-002-0569-y Sariyildiz T, Anderson JM (2005). Variation in the chemical composition of green leaves and leaf litters from three deciduous tree species growing on different soil types. Forest Ecology and Management 210 (1-3): 303-319. - doi: 10.1016/j. foreco.2005.02.043

Sariyildiz T, Anderson JM, Kucuk M (2005). Effects of tree species and topography on soil chemistry, litter quality and decomposition in northeast Turkey. Soil Biology and Biochemistry 37 (9): 1695-1706. - doi: 10.1016/j.soilbio. 2005.02.004
Sariyildiz T, Küçük M (2008). Litter mass loss rates in deciduous and coniferous trees in Artvin, northeast Turkey: relationships with litter quality, microclimate, and soil characteristics. Turkish Journal of Agriculture and Forestry 32 (6): 547-559. [online] URL: http://journals.tu bitak.gov.tr/agriculture/abstract.htm?id=9870

Satti P, Mazzarino MJ, Gobbi M, Funes F, Roselli $\mathrm{L}$, Fernandez H (2003). Soil $\mathrm{N}$ dynamics in relation to leaf litter quality and soil fertility in north-western Patagonian forests. Journal of Ecology 91: 173-181. - doi: 10.1046/j.1365-2745.20 03.00756.x

Scott NA, Binkley D (1997). Foliage litter quality and annual net $\mathrm{N}$ mineralization: comparison across North American forest sites. Oecologia 111: 151-159. - doi: 10.1007/s004420050219

Sharma E, Ambasht RS (1987). Litterfall, decomposition and nutrient release in an age sequence of Alnus nepalensis plantation stands in the eastern Himalaya. The Journal of Ecology 75 (4): 997. - doi: 10.2307/2260309

Sharma E, Ambasht RS, Sing MP (1985). Chemical soil properties under five age series of Alnus nepalensis plantations in the Eastern Himalayas. Plant and Soil 84 (1): 105-113. - doi: 10.1007/BFo 2197871

Shen H, Wang X, Jiang Y, You W (2012). Spatial variations of throughfall through secondary succession of evergreen broad-leaved forests in eastern China. Hydrological Processes 26 (11): 1739-1747. - doi: 10.1002/hyp.v26.11

Singh KP, Singh PK, Tripathi SK (1999). Litterfall, litter decomposition and nutrient release patterns in four native tree species raised on coal mine spoil at Singrauli, India. Biology and Fertility Soils 29 (4): 371-378. - doi: 10.1007/s003740 050567

Sinsabaugh RL, Antibus RK, Linkins AE, McClaugherty CA, Rayburn L, Repert D, Wei-land T (1993). Wood decomposition: nitrogen and phosphorus dynamics in relation to extracellular enzyme activity. Ecology 74 (5): 1586-1593. doi: $10.2307 / 1940086$

Smithwick EA, Turner MG, Metzger KL, Balser TC (2005). Variation in $\mathrm{NH}^{4+}$ mineralization and microbial communities with stand age in lodgepole pine (Pinus contorta) forests, Yellowstone National Park (USA). Soil Biology and Biochem- istry 37 (8): 1546-1559. - doi: 10.1016/j.soilbio.200 5.01.016

Trap J, Bureau F, Vinceslas-Akpa M, Chevalier R, Aubert M (2009). Changes in soil $N$ mineralization and nitrification pathways along a mixed forest chronosequence. Forest Ecology and Management 258: 1284-1292. - doi: 10.1016/j.for eco.2009.06.021

Trap J, Hättenschwiler S, Gattin I, Aubert M (2013). Forest ageing: an unexpected driver of beech leaf litter quality variability in European forests with strong consequences on soil processes. Forest Ecology and Management 302: 338-345. - doi: 10.1016/j.foreco.2013.03.011

Trogisch S, He JS, Hector A, Scherer-Lorenzen M (2016). Impact of species diversity, stand age and environmental factors on leaf litter decomposition in subtropical forests in China. Plant and Soil 400 (1-2): 337-350. - doi: 10.1007/s11104015-2737-5

Wang J, You Y, Tang Z, Liu S, Sun OJ (2014). Variations in leaf litter decomposition across contrasting forest stands and controlling factors at local scale. Journal of Plant Ecology 8 (3): 261272. - doi: 10.1093/jpe/rtu019

Wei L, Danli Y, Ji L, Yongmei HE (2020). Medium and long term decomposition process of litter in Abies fabri forest. Journal of Landscape Research 12 (1): 127-136. -doi: 10.16785/j.isnn1943-9 89x.2020.1.027

Welke SE, Hope GD (2005). Influences of stand composition and age on forest floor processes and chemistry in pure and mixed stands of Douglas-fir and paper birch in interior British Columbia. Forest Ecology and Management 219 (1): 29-42. - doi: 10.1016/j.foreco.2005.08.040

Wu F, Yang W, Zhang J, Deng R (2010). Litter decomposition in two subalpine forests during the freeze-thaw season. Acta Oecologica 36 (1): 135-140. - doi: 10.1016/j.actao.2009.11.002

Wu Q, Wu F, Yang W, Zhao Y, He W, Tan B (2014). Foliar litter nitrogen dynamics as affected by forest gap in the Alpine forest of eastern Tibet Plateau. PLoS One 9 (5): e97112. - doi: 10.1371/ journal.pone.0097112

Yu S, Wang D, Dai W, Li P (2014). Soil carbon budget in different-aged Chinese fir plantations in south China. Journal of Forestry Research 25 (3): 621-626. - doi: 10.1007/s11676-014-0500-z 